\title{
PLURALITAS AGAMA DALAM PANDANGAN KRISTEN DAN IMPLIKASINYA BAGI PENGAJARAN PAK
}

\author{
Stanley R. Rambitan \\ Universitas Kristen Indonesia \\ Program Studi Magister Pendidikan Agama Kristen \\ stanley_rambitan@yahoo.com
}

\begin{abstract}
Abstrak
Makalah ini berisi pembahasan tentang pandangan Kekristenan mengenai pluralitas dan agama dan bagaimana itu menjadi dasar bersikap secara teologis-etis dari umat Kristen, khususnya dalam pengajaran pendidikan agama Kristen. Pluralitas agama adalah kenyataan mutlak dalam kehidupan masyarakat khususnya di Indonesia. Pandangan dan sikap agama dan umat Kristen bersifat lebih positif daripada negatif. Kemajemukan agama diterima secara kritis, khususnya dalam umat Kristen melaksanakan tugas membawa kabar keselamatan Allah melalui Yesus Kristus. Lebih khusus, dalam mengajarkan pendidikan agama Kristen, diharapkan kondisi plural agama ini dijadikan materi pelajaran atau bahan ajar yang memampukan siswa atau umat Kristen menyikapi dan menjalankan tugasnya sebagai orang Kristen secara positif dan efektif. Data yang dipergunakan dalam tulisan ini diperoleh dengan studi literatur atau kepustakaan, sedangkan penyajian materi dilakukan dengan analisis deskriptif- kualitatif dengan corak isi diwarnai oleh studi alkitabiah dan PAK.
\end{abstract}

Kata-kata Kunci: Pluralitas agama, pluralisme, toleransi dan PAK Kontemporer

\section{Pendahuluan}

Saat ini, tidak ada lagi suatu tempat dan komunitasnya yang tidak mengalami perjumpaan dengan unsur budaya, termasuk agama, dari tempat dan masyarakat lain; atau bahkan yang tidak tersentuh dan terpengaruh oleh unsur lain itu. Hadirnya agama lain di dalam suatu masyarakat telah menghasilkan keanekaragaman atau pluralitas agama. Bangsa atau masyarakat yang dahulunya homogen dalam agama telah menjadi heterogen. Misalnya, bangsa dan budayaagama Asia dan Afrika yang dimasuki oleh bangsa dan budaya Barat, termasuk Kristen, di jaman kolonialisme dan penyebaran Kekristenan di abad 17-20; atau mulai di pertengahan abad 19 dan 20, masuknya umat Hindu, Buddha dan Islam ke Barat (Eropah dan Amerika Utara). Ini mengakibatkan terjadinya perjumpaan Barat-Kristen dengan Hindu, Buddha dan Islam dan menjadikan dunia Barat itu tidak lagi homogen Kristen tetapi sudah menjadi masyarakat plural agama. Pluralitas budaya, khususnya agama, telah menjadi realitas yang bahkan sudah mutlak di dalam kelompok-kelompok masyarakat di bumi ini. Satu bumi, banyak agama, itulah judul buku Paul F. Knitter mengenai realitas plural agama-agama dan bagaimana sikap-sikap yang diperlihatkan terhadapnya; juga bagaimana dialog dapat 
dilaksanakan sebagai bentuk tanggung jawab global umat beragama. ${ }^{1}$

Terhadap pluralitas agama, pluralisme menjadi konsep dan sikap yang sangat penting. Pluralisme agama di sini berarti pemahaman dan penghayatan sekaligus penerimaan terhadap kenyataan bahwa ada agama-agama lain yang berbeda dengan kita dan bahwa di dalam agama-agama itu Allah menyatakan dirinya secara khusus juga, dan karena itu di dalam agama-agama yang ada, orang dapat menemukan Allah dan mendapatkan ridha, berkat dan keselamatan dari-Nya. Di samping atau bersamaan dengan itu, istilah toleransi juga sering dipergunakan sebagai sikap rela menerima kenyataan bahwa ada pihak-pihak lain yang berbeda di sekitar kita. Toleransi di sini mengandung di dalamnya makna sabar, rela, atau pasrah menerima. Pemahaman ini memperlihatkan bahwa toleransi adalah sikap menerima keadaan yang sebenarnya tidak disukai. Ada beban yang ditangung yang sebenarnya tidak dikehendaki. Karena itu, istilah toleransi dalam rangka

\footnotetext{
${ }^{1}$ Paul F. Knitter, One Earth, Many Religions: Multifaith Dialogue \& Global Responsibility (New York: Orbis Books, 1995). Knitter merupakan salah seorang di antara sekian banyak teolog di kalangan Kristen yang memperlihatkan perhatian yang serius dan optimis terhadap isu pluralisme/pluralitas agama. Tokoh lain adalah: Karl Barth, Paul Tillich, Karl Rahner, W.C. Smith, John Hick, Raimundo Panikkar, M.M. Thomas, Stanley S. Samartha, Leslie Newbigin, dan Hans Kung. Di Indonesia, tokoh-tokoh yang dikenal adalah Th. Sumartono, Olaf Schumann dan Eka Dharmaputera.
}

pluralitas agama berkonotasi atau memiliki makna negatif. Namun sikap toleran merupakan sikap positif karena mendukung kerukunan dan persatuan serta menghindari konflik. Istilah toleransi mengandung di dalamnya ketidak-tulusan. Hal ini karena pada dasarnya, pihak lain yang berbeda itu diterima secara tidak menyenangkan, atau diterima dengan berat hati. Oleh karena itu, Paul Knitter mengatakan bahwa toleransi beragama itu didasarkan pada dan berorientasi pada pandangan dan sikap yang acuh tak acuh terhadap pihak agama lain. Memang, istilah toleransi umumnya dipergunakan dalam lingkungan politik, khususnya berhubungan dengan pihak-pihak yang dibedakan karena status mayoritas atau minoritas, atau pihak yang berkuasa dan yang dikuasai. Dan karena itu, istilah toleransi lebih cocok dipergunakan dalam dunia sosial-politik, bukan dalam hal agama. $^{2}$

Sebagai bagian dari pluralitas agama, Kekristenan tentu memiliki pandangan dan sikap terhadap pluralitas agama. Itu tentu memiliki makna dan pengaruh bagi kehidupan bersamanya dalam masyarakat. Di bawah ini akan dibahas pandangan dan sikap Kristen terhadap pluralitas agama dan

\footnotetext{
${ }^{2}$ Karena itu juga maka di dalam makalah ini, toleransi tidak akan menjadi sorotan utama, tapi hanya akan disinggung sebagaimana diperlukan.
} 
menjadikannya pertimbangan dalam materi pengajaran Pendidikan Agama Kristen (PAK). Pembahasan akan pertamatama memperlihatkan bagaimana kitab suci Kristen, yaitu Alkitab, berbicara tentang pluralisme. Ini penting karena Alkitab adalah dasar dan sumber iman dan ajaran Kristen. Segala pengajaran yang berkembang di kalangan Kristen selalu didasarkan pada Alkitab. Selanjutnya, akan dibahas tentang pluralitas agama dalam pandangan atau wacana kalangan Kristen kontemporer. Ini penting untuk memperlihatkan bagaimana para tokoh atau teolog Kristen (baik Katolik maupun Protestan) memahami dan menyikapinya. Pembahasan ini akan menunjukkan bahwa hal pluralitas agama telah menjadi perhatian penting di kalangan Kristen. Pembahasan terakhir adalah mengenai bagaimana kenyataan pluralitas agama dan konsep pluralisme itu menjadi pertimbangan dan dijadikan materi pokok dalam pengajaran PAK di lembagalembaga pendidikan dan gereja.

\section{Pandangan Alkitab tentang Pluralitas} Agama

Alkitab sebagai kitab suci agama Kristen menjadi sumber setiap ajaran dan praktek hidup umatnya. Alkitab terbagi dua bagian, yaitu pertama yang disebut Perjanjian Lama (PL) dan kedua Perjanjian Baru (PB). Perjanjian Lama berisi berbagai cerita menyangkut hubungan antara Tuhan-Allah dan manusia, dari manusia pertama sampai sejarah kehidupan bangsa Israel yang dipahami sebagai umat atau bangsa pilihan Allah. PL terutama berisi pengalaman dan refleksi hidup beragama bangsa Israel yang dimulai dengan riwayat manusia pertama dan leluhur-leluhur Israel seperti Abraham, Ishak dan Yakub, lalu tokoh-tokoh penting seperti Musa, Yosua, para raja dan juga para nabi sampai jaman sesudah pembuangan Babel sekitar tahun 400-an SM. Dalam sejarah bangsa Israel itu, hubungan Allah dan bangsa itu dituliskan, dan bahwa kitab-kitab itu juga diakui oleh Yesus sebagai kitab pengajaran utama. Karena alasan ini maka umat Kristen mangakui PL juga sebagai kitab suci. Karena itu, pandangan dan sikap Alkitab menyangkut pluralisme penting untuk dibahas di sini. Perjanjian Baru berisi akar-akar Kekristenan yang dimulai dari jaman atau oleh Yesus, yang tertulis di dalam empat kitab Injil (yaitu Matius, Markus, Lukas dan Yohanes), dan tulisantulisan rasul Paulus, Petrus dan pengikutpengikut Yesus lainnya. Kitab-kitab Injil berisi perkataan-perkataan, ajaran dan perbuatan-perbuatan Yesus sampai Dia mati dibunuh di kayu salib. Tulisan-tulisan Paulus, Petrus dan para pengikut lainnya itu berisi nasehat-nasehat, ajaran-ajaran tentang Yesus dan bagaimana kehidupan orang Kristen yang benar. 
Sebagai kitab suci, tentu kedua kitab ini (PL dan PB) menjadi dasar dan rujukan utama bagi pandangan dan sikap orang Kristen. Karena itu di bahwah ini akan diberikan uraian tentang pandangapandangan Alkita itu tentang pluralisme dan toleransi.

\section{a. Perjanjian Lama}

Dalam sejarah bangsa Israel sebagaimana tertulis di dalam PL, tampak bahwa Israel telah hidup di dalam lingkungan masyarakat yang pluralis. Banyak bangsa dan agama lain yang hidup berdampingan dengan bangsa Israel. Leluhur bangsa Israel juga sudah mengalami perjumpaan dengan bangsabangsa lain. Misalnya Abraham dan keturunannnya, seperti Ishak dan Yakub. Bahkan mereka juga sempat hidup di wilayah kekuasaan bangsa lain. Contoh yang paling jelas adalah Abraham yang keluar dari Ur di kota Kadim dan pergi hidup berpindah-pindah di daerah bangsabangsa lain, sampai keturunannya (yaitu dua belas suku Israel) hidup di dalam perbudakan di Mesir. Di Mesir, tokoh Musa menjadi penting karena dialah yang memimpin pembebasan bangsa Israel dari perbudakan di negeri itu. Bangsa Israel lalu hidup 40 tahun dalam perjalanan di padang gurun untuk pergi dan menduduki tanah yang dijanjikan, yaitu Kanaan. Di bawah kepemimpinan Yosua, mereka berhasil merebut tanah perjanjian. Israel menjadi kerajaan dengan raja-raja yang terkenal, seperti Daud dan Salomo. Di bawah kepemimpinan raja-raja ini, Israel hidup dalam kejayaan. Tetapi penggantipengganti mereka hidup dalam kelaliman sehingga Tuhan menghukum Israel. Kerajaan runtuh dan bangsa Israel dibuang ke Babel. Tetapi sekitar 200-an tahun kemudian mereka dibebaskan. Peristiwa ini adalah akhir dari cerita di dalam PL. ${ }^{3}$ Dalam sejarah yang tidak tercatat dalam PL, bangsa Israel (Yahudi) dikuasai oleh Yunani dan kemudian Romawi. Di jaman penjajahan Romawi, Yesus muncul dan berkarya.

Dari pengalaman perjumpaan bangsa Israel dengan bangsa-bangsa lain, sikap umum atau dominan yang diperlihatkan adalah sikap eksklusif dan superior. Israel pada posisi khusus, diakui sebagai bangsa pilihan. Sebagai bangsa pilihan, ia diistimewakan, yaitu mendapat berkat dan perlindungan Allah. Ia bahkan dipakai sebagai saluran berkat bagi bangsa-bangsa lain. Dalam status ini, bangsa Israel berada pada posisi untuk menilai bangsa-bangsa lain. Terutama yang dikritik adalah bangsa-bangsa yang lalim dan memusuhi Israel. Yang dikritik adalah kejahatan atau pihak yang jahat,

\footnotetext{
${ }^{3}$ Mengenai sejarah bangsa Israel itu, lihat terutama kitab-kitab Keluaran, Ulangan, Yosua, HakimHakim, I \& II Tawarikh, dan beberapa Kitab nabiNabi.
} 
baik yang ada pada bangsa-bangsa lain maupun yang ada di kalangan bangsa Israel sendiri. Allah bangsa Israel tidak toleran terhadap bangsa yang lalim. Bangsa lain juga dikritik dan dimusuhi karena mereka menyembah berhala/baal. Terhadap bangsa-bangsa dan kejahatan seperti ini, bangsa Israel diberi tugas untuk menobatkan mereka. Kasus Yunus, yang dikirim Allah untuk menyampaikan pesan kepada bangsa Niniwe memperlihatkan pelaksanaan tugas untuk membawa keselamatan kepada bangsa lain. Di sini ada pemahaman bahwa bangsa lain perlu diselamatkan. Karena itu, adalah tugas nabi-Israel untuk menyampaikan pesan Allah kepada mereka supaya mereka bertobat. $^{4}$

Jadi bangsa-bangsa/agama-agama lain dilihat sebagai pihak yang tidak selamat dan perlu diselamatkan. Pluralitas bangsa/agama di sini tidak dipahami dan disikapi sebagai sebuah keragaman yang harus diterima, tetapi yang harus diselamatkan dengan membuat bangsa yang berbeda itu bertobat dan beralihpercaya kepada Allah. Kota Niniwe yang kemudian bertobat, diampuni dan diselamatkan Tuhan. Yunus yang semula diberi tugas untuk menyampaikan pesan ke kota Niniwe (tetapi membelot) menjadi marah atau iri hati karena Allah

\footnotetext{
${ }^{4}$ Lihat cerita Yunus di dalam kitab Yunus.
}

membebaskan Niniwe dari penghukuman. Yunus di sini sebenarnya mewakili sikap bangsa Israel yang merasa sebagai bangsa terpilih dan yang ingin memonopoli kasih Allah kepada bangsa-bangsa lain. Tetapi Allah mengasihi penduduk Niniwe, dan kasih-Nya itu tidak dapat dikalahkan oleh kekecewaan Yunus. Cerita Yunus ini memperlihatkan bahwa Allah mengasihi bangsa-bangsa lain.

Dalam sejarah bangsa Israel, sebagai implikasi dari penolakan terhadap pluralitas dan toleransi, ada bangsa-bangsa lain yang diperangi dan dikuasai, khususnya bangsa-bangsa yang mendiami daerah-daerah di Palestina, yaitu tanah yang dijanjikan Tuhan. Bangsa-bangsa yang diperangi misalnya kota Yerikho (Yosua 6), Ai (Yosua 8), bangsa Het, Amori, Kanaan, Feris, Hewi dan bangsa Yebus, Amon, dll (Yosua 9-24). Peperangan dalam rangka perebutan daerah kekuasaan ini bukan didasarkan pada penolakan terhadap keberadaan bangsa-bangsa itu karena mereka menyembah ilah lain, jadi bukan karena anti-pluralisme, tetapi karena bangsabangsa lain itu mendiami tanah yang dijanjikan dan diberikan Allah. Untuk merebut tanah itu, bangsa Israel harus melakukan peperangan. Dengan kata lain, peperangan yang dilakukan terhadap bangsa lain bukan karena perbedaan 
agama tetapi karena janji Tuhan untuk memberikan tanah itu. ${ }^{5}$

Namun demikian, ada pandangan yang berbeda dari yang di atas, yaitu adanya pengakuan terhadap otoritas, perlindungan Allah dan pengangkatan oleh Allah terhadap bangsa- bangsa lain. Ternyata, ada bangsa-bangsa lain yang diakui sebagai bangsa yang diberkati Allah, yaitu Mesir dan Asyur (yang sebenarnya adalah musuh-musuh Israel). Firman Tuhan melalui nabi Yesaya mengatakan:

Pada waktu itu akan ada mezbah bagi TUHAN di tengah-tengah tanah Mesir dan tugu peringatan bagi TUHAN pada perbatasannya. Itu akan menjadi tanda kesaksian bagi TUHAN semesta alam di tanah Mesir: apabila mereka berseru kepada TUHAN oleh karena orang-orang penindas, maka Ia akan mengirim seorang juruselamat kepada mereka, yang akan berjuang dan akan melepaskan mereka. Tuhan akan menyatakan diri kepada orang Mesir, dan orang Mesir akan mengenal Tuhan pada waktu itu; mereka akan beribadah dengan korban sembelihan dan korban sajian, dan mereka akan bernazar kepada TUHAN serta membayar nazar itu. ${ }^{6}$

\footnotetext{
${ }^{5}$ Sebenarnya, peperangan yang dilakukan oleh bangsa Israel terhadap bangsa-bangsa lain itu karena kepentingan politis-kekuasaan, yaitu demi merebut daerah untuk didiami dan dikuasai. ${ }^{6}$ Alkitab, Yesaya 19:19-21; lihat juga pembahasan Ariarayah, Alkitab dan Orang-orang Yang
}

Lebih dari itu, menurut nabi Yesaya, bangsa-bangsa lain adalah sama dengan bangsa Israel dan bangsa Israel sama dengan bangsa-bangsa lain. Firman itu mengatakan:

Pada waktu itu akan ada jalan raya dari Mesir ke Asyur, sehingga orang Asyur dapat masuk ke Mesir dan orang Mesir ke Asyur, dan Mesir akan beribadah bersamasama Asyur. Pada waktu itu Israel akan menjadi yang ketiga di samping Mesir dan Asyur, suatu berkat di atas bumi, yang diberkati oleh TUHAN semesta alam dengan berfirman: "Diberktilah Mesir, umatKu, dan Asyur, buatan tanganKu dan Israel, milik pusakaKu.",7

Tambahan lagi, yang menunjukkan bangsa lain sebagai alat dan sarana berkat Tuhan adalah pernyataan nabi Yesaya:

Inilah FirmanKu kepada orang yang Kuurapi, kepada Koresy yang tangan kanannya Kupegang supaya Aku menundukkan bangsa-bangsa di depannya dan melucuti raja-raja, supaya Aku membuka pintu-pintu di depannya dan supaya pintu-pintu gerbang tidak tinggal tertutup. ${ }^{8}$

Di sini tampak jelas bahwa Allah memilih dan memakai raja bangsa lain (Koresy adalah raja Persia) sebagai tangan

Berkepercayaan Lain (Terj.) (Jakarta: BPK-GM), 11.

${ }^{7}$ Alkitab, Yesaya 19:23-25; lihat Ariarayah, Ibid., 11-12.

${ }^{8}$ Alkitab, Yesaya 45; 1 ; liha juga Ariyarajah, Ibid., 12. 
kanan-Nya untuk menundukkan raja-raja bangsa lain. Pengakuan dan penerimaan terhadap kebenaran bangsa lain sehingga mereka juga diakui, diberkati dan dipakai oleh Allah karena kenyataannya adalah bahwa bangsa lain juga adalah ciptaan Allah dan Allah mengasihi mereka. Nenek moyang mereka adalah leluhur-leluhur yang saling bersaudara atau satu keturunan dan satu sumber, yaitu Allah Sang Pencipta. Leluhur mereka adalah Abraham/Ibrahim, Nuh dan Adam-Hawa. Oleh karena itu, sekalipun diakui, tegas dinyatakan dan umum dipahami bahwa bangsa Israel adalah bangsa pilihan Allah, tetapi bukan berarti Allah tidak memberkati bangsa lain. Allah tetap memberkati bangsa-bangsa lain. Bahkan, bangsa lain juga difungsikan Allah untuk menegur Israel atau menjadi saluran berkat bagi Israel (misalnya Mesir yang dipakai Allah untuk menyediakan makanan bagi bangsa Israel ketika mereka mengalami kelaparan). Di dalam kondisi perang antara bangsa Israel dengan bangsa lain, ada saat Israel mengalahkan mereka tetapi juga ada saat mereka mengalahkan Israel.

Dari pemaparan tentang pandangan dan sikap Alkitab PL terhadap pluralitas di atas, nyata bahwa di samping pengakuan terhadap bangsa Israel sebagai bangsa pilihan, bahwa Tuhan ternyata juga menerima dan mengakui keberadaan bangsa-bangsa lain. Allah mengasihi dan memberkati mereka. Kenyataan ini memperlihatkan beragam sikap terhadap pluralitas, yaitu eksklusif dan pluralis; serta toleran, kompromis dan bahkan submisif terhadap kenyataan bahwa ada pihak-pihak lain di sekitar dan mereka bahkan dikasihi dan dijadikan tangan kanan Allah juga.

\section{b. Perjanjian Baru}

Sumber utama bagi pandangan dan sikap Kristen dalam Alkitab Perjanjian Baru tentang pluralisme dan toleransi adalah teladan yang diperlihatkan Yesus. Yesus atau agama Kristen muncul, berkarya dan beredar mulai-mula di dalam kalangan masyarakat dan agama Yahudi. Jadi ketika hal itu muncul, pluralitas sudah menjadi bagiannya. Karena itu, ajaran Yesus menyangkut pluralisme dipengaruhi oleh perjumpaan-Nya dengan agamaagama lain, terutama Yahudi dan Helenisme (budaya-agama Yunani). Secara garis besar, partikularisme atau eksklusivisme yang melihat Yesus dan ajaran-Nya sebagai kebenaran utama atau yang satu-satunya tampak mendominasi ajaran Perjanjian Baru, baik teologi kitabkitab Injil maupun surat-surat Paulus, serta surat-surat umum. Yesus dilihat sebagai satu-satunya jalan kepada keselamatan. Kitab Injil Yohanes memperlihatkan keistimewaan peran Yesus: 
Karena begitu besar kasih Allah akan dunia ini sehingga Ia telah mengaruniakan anakNya yang tunggal supaya setiap orang yang percaya kepadanya beroleh hidup yang kekal. 9 Kata Yesus kepadanya: "Akulah jalan dan kebenaran dan hidup. Tidak ada seorang pun yang datang kepada Bapa, kalau tidak melalui Aku. ${ }^{10}$

Jadi di sini tampak adanya pandangan yang eksklusif atau partikular dari perkataan Yesus itu: bahwa Dia adalah jalan menuju kepada Allah atau Dia adalah jalan keselamatan. Ajaran partikular ini mewarnai ajaran Alkitab PB dan Kekristenan di sepanjang sejarah sampai saat ini. Ini adalah ajaran inti dalam agama Kristen, yaitu bahwa Yesus adalah Juruselamat; ia memberikan atau mengantar manusia pada jalan yang benar menuju Tuhan dan mencapai keselamatan.

Walaupun demikian, Yesus tidak menolak kehadiran bangsa/umat lain ada di sekitarnya. Yesus juga tidak memberikan penilaian negatif, atau Dia menganggap buruk atau jahat bangsabangsa lain itu. Yesus menerima keberadaan bangsa-bangsa lain dan mau bergaul dengan mereka, dan bahkan mengambil contoh yang baik dari bangsa asing itu bagi ajaran moral-etis-Nya. Misalnya, ilustrasi “Orang Samaria yang

\footnotetext{
${ }^{9}$ Alkitab, Injil Yohanes 3: 15.

${ }^{10}$ Alkitab, Yohanes 14:6.
}

baik hati."11 Bahkan terhadap kelompok yang dianggap sebagai musuh oleh masyarakat dan agama-adat Yahudi, seperti bangsa/orang Samaria yang mau bertemu dan bercakap-cakap. Jadi, bangsabangsa lain oleh Yesus, dan juga kemudian oleh rasul-rasul (murid-murid atau sahabat-sahabatnya), diakui dan dipahami sebagai pihak yang perlu mendengar berita kesukaan atau Injil yang dibawa-Nya.

Pandangan dan sikap Yesus terhadap bangsa/agama lain menunjukkan pengakuan dan penerimaan terhadap eksistensi mereka; dan bahwa mereka adalah bangsa yang perlu diperlakukan secara baik, yaitu dengan memberikan perhatian dan mengangkat harkat martabat hidup mereka. Juga bahwa, masyarakat lain ini menjadi tempat menyampaikan kabar baik, Injil atau berita keselamatan, supaya mereka dapat selamat; atau supaya mereka dapat dibebaskan dari belenggu kebodohan, kemiskinan, kesakitan dan penderitaan, dan mereka dapat hidup damai sejahtera.

Untuk melaksanakan usaha itu, orang harus memiliki iman yang kuat dan hidup dengan menerapkan cinta kasih (sesuai hukum kasih: kepada Allah dan kepada manusia). Tugas ini sudah dilaksanakan oleh Yesus dan kemudian dia mengutus murid-murid-Nya untuk

\footnotetext{
${ }^{11}$ Lihat, Alkitab, Lukas 10:25-37.
} 
melanjutkan karya itu ke dalam kehidupan dunia. Perintah Yesus adalah:

Yesus mendekati mereka dan berkata: "KepadaKu telah diberikan segala kuasa di sorga dan di bumi. Karena itu pergilah, jadikanlah semua bangsa muridKu dan baptislah mereka dalam nama Bapa dan Anak dan Roh Kudus, dan ajarlah mereka melakukan segala sesuatu yang Kuperintahkan kepadamu. Dan ketahhuilah, Aku menyertai kamu senantiasa sampai kepada akhir zaman."12

Perkataan Yesus ini disebut oleh kebanyakan orang Kristen sebagai Amanat Agung atau perintah mulia dari Yesus. Hal ini dipegang, khususnya oleh kalangan Kristen ortodoks sebagai tugas utama yang diberikan Yesus kepada umat Kristen. Di dalamnya mengandung makna tentang pandangan dan sikap terhadap dunia atau pihak lain. Bahwa bangsa (termasuk umat agama lain) adalah pihak yang menjadi tujuan untuk menyampaikan kabar keselamatan. Jadi pihak lain dipandang dan disikapi dalam rangka tugas kesaksian, atau tugas menyampaikan berita keselamatan. Keberadaan mereka tidak ditolak, tetapi dianggap sebagai pihak yang belum selamat sehingga perlu diselamatkan. Tugas kesaksian ini dilakukan kepada bangsa-bangsa. Seperti Yesus katakan : “... dan kamu akan menjadi saksi-Ku di Yerusalem dan di

\footnotetext{
${ }^{12}$ Alkitab, Matius 28:16-20.
}

seluruh Yudea dan Samaria dan sampai ke ujung bumi.",13

Ajaran atau keyakinan di atas telah mendorong banyak orang Kristen, mulai dari awal sejarah gereja, dalam diri para rasul, sampai saat ini di dalam diri para misionaris, untuk melakukan pekabaran Injil (yang oleh kalangan agama lain dinilai sebagai usaha Kristenisasi). Jadi, di dalam ajaran Alkitab, pluralitas agama atau adanya umat yang memiliki kepercayaan lain, dinilai sebagai suatu kondisi yang baik, yang bahkan menjadi tempat bagi penyebaran dan persemaian nilai-nilai kerajaan Allah. Di sini, pluralisme dipahami sebagai sesuatu yang perlu ada; namun itu bukan ada untuk dirinya sendiri. Pluralisme bersifat sosialkultural dan historis, bukan pluralisme teologis-doktrinal. Hal ini karena, sekalipun mengakui keberadaan pihakagama lain, namun mereka masih dianggap sebagai pihak yang memiliki kekurangan, yaitu kebutuhan akan keselamatan. Menjadi tugas pengikut Yesus-lah untuk membawa mereka kepada keselamatan. Untuk melakukan tugas ini, orang Kristen diajarkan untuk bersedia menderita (atau memikul salib) atau bahkan mati. Inilah yang dilakukan oleh para murid Yesus pada awal perkembangan sejarah gereja

\footnotetext{
${ }^{13}$ Alkitab, Kisah Para Rasul 1:8. Bandingkan B. Sidjabat, Religious Tolerance and The Christian Faith (Jakarta: BPK-GM, 1982).
} 
dan kemudian di jaman penyebaran Kekristenan selanjutnya.

Dalam kerangka pemahaman ajaran seperti itu, toleransi bukan merupakan istilah yang cocok. Toleransi hanya menjadi relevan jika keadaan sekitar, atau adanya pihak-pihak yang berbeda, tidak dikehendaki. Tetapi di dalam ajaran Alkitab, justru pengikut Yesus atau orang Kristen akan merasa senang jika mereka berada di dalam masyarakat yang plural atau pergi ke daerah yang terdiri dari berbagai latarbeakang budaya dan agama karena tempat atau masyarakat seperti itu menjadi tempat bagi pelaksanaan tugas kesaksian tentang Yesus yang menyelamatkan.

Dari ajaran Yesus dalam PB tampak bahwa ada pandangan dan sikap eksklusif di dalam berhadapan dengan pluralitas. Namun itu tidak menunjukkan penolakan atau antipati Yesus terhadapnya. Pluralitas diterima, dipahami dan dihargai sebagai sebuah kenyataan mutlak. Terhadap pluraitas seperti ini, yang diajarkan Yesus, seperti dalam contoh yang Dia lakukan terhadap perempuan Samaria, adalah perjumpaan yang proaktif dan melakukan dialog. Ini dimaksudkan dan berfungsi menghasilkan saling paham, saling menerima dan saling mengangkat harkat dan martabat hidup. Yesus mengambil contoh atau teladan yang baik dari pihak lain. Dalam hal ini, cerita tentang orang Samaria yang baik hati. $^{14}$ Jadi di samping penerimaan terhadap pluralitas/pluralisme, penerimaan itu harus bermanfaat dan menjadi berkat, membawa damai sejahtera bagi semua pihak.

\section{Wacana Pluralisme dalam Teologi Kristen Kontemporer}

Dalam sejarah perkembangan agama Kristen, khususnya dalam berhadapan dengan pihak-pihak yang berbeda, pandangan eksklusif dan superior kerap mewarnai perilaku umat Kristen. Hal ini telah menyebabkan berbagai konflik, baik dalam lingkungan Kekristenan sendiri (misalnya Katolik berhadapan dengan Protestan), maupun dalam berhadapan dengan umat agama berbeda (seperti tragedi perang salib). ${ }^{15}$ Namun sejarah telah memberi pelajaran yang berarti sehingga dengan pelajaran itu banyak orang Kristen di kemudian hari berusaha untuk menjalin hubungan yang baik dengan pihak-pihak umat agama lain. Hal ini dilakukan melalui studi terhadap agama-agama yang telah menimbulkan penghargaan yang tinggi terhadap agama lain, dan juga melalui usaha-usaha dialog dan kerjasama. Hal ini dapat menjadi

\footnotetext{
${ }^{14}$ Alkitab, Lukas 10: 25-37.

${ }^{15}$ Lihat soal ini dalam Th. van den End \& Chr. De Jonge, Sejarah Perjumpaan Gereja dan Islam (Jakarta: Sekolah Tinggi Teologi Jakarta, 1997); Jan S. Aritonang, Sejarah Perjumpaan Kristen dan Islam di Indonesia (Jakarta: BPK-GM, 2004).
} 
petunjuk adanya pengakuan dan penerimaan terhadap pluralitas agama.

Dalam wacana umum, khususnya yang dipengaruhi oleh penelitian ilmiah terhadap agama, ada berbagai pandangan tentang agama dalam kaitannya dengan pluralisme. Pertama, relativisme, yaitu pandangan yang mengatakan bahwa kebenaran agama adalah relatif. Setiap agama memiliki keistimewaan, kelebihan dan kekurangannya. Bagi penganut agama yang satu, agamanya yang benar, tetapi bagi yang lain, agamanya yang benar. Kedua, bahwa agama-agama sama saja antara satu dengan yang lain. Inti atau esensi agama adalah satu dan sama saja. Yang membedakannya adalah manifestasi atau perwujudan atau ekspresi agama yang tampak pada kredo-doktrin atau kepercayaan, ritus-ritus, simbol-simbol dan nilai-nilai etis-moral dan hukumnya. Juga, asal-usul psikologis agama-agama adalah sama. Munculnya kepercayaan atau iman dan kemudian menjadi sistem kepercayaan atau agama disebabkan oleh kebutuhan akan kehidupan yang damai dan tenang. Maka sosok ilahi menjadi pemenuhan akan kebutuhan ini. Terakhir, bahwa setiap agama memiliki peran penting di dalam diri manusia dan di dalam masyrakat; agama menjadi pegangan atau jaminan hidup individual, dan menjadi sumber nilai moral-etis dan spiritual masyarakat. ${ }^{16}$

Di kalangan umat Kristen, muncul model-model sikap terhadp pluralisme. Pertama, model kaum konservatif-Injili, yang memahami bahwa hanya ada satu agama yang benar dan agama yang benar itu harus memenuhi ukuran kitab suci Kristen atau Alkitab. Menurut Alkitab bahwa hanya Yesus yang menjadi Juruselamat. Agama-agama lain tidak menyediakan keselamatan itu. Pandangan ini dapat disebut inklusif-mutlak atau ekstrim. Kedua, model kaum Protestan arus utama, yang mengutamakan pandangan positif dan sikap dialogis terhadap agama-agama lain. Kaum ini mengakui adanya adanya penyataan umum (bukan hanya yang partikular di dalam Yesus Kristus), yaitu dalam penampakan alam semesta ini. pernyataan umum Allah ini dapat juga berwujud dalam budaya atau agama-agama yang ada. Pandangan ini tidak menerima bahwa di dalam agamaagama lain ada keselamatan karena agamaagama itu menganjurkan agama dan penganutnya mencari keselamatan dengan melakukan perbuatan-perbuatan tertentu, tidak berdasarkan iman kepada Tuhan. Apalagi agama-agama lain ini tidak memiliki hubungan dengan Yesus yang

\footnotetext{
${ }^{16}$ Lihat, Knitter, No Other Name? bandingkan dengan G. van der Leeuw, Religion in Essence and Manifestation. (London: Allan and Unwin, 1938).
} 
merupakan penyataan Allah yang partikulir. Ketiga, model kaum Katolik, bahwa ada banyak jalan tetapi ukurannya satu, yaitu Yesus Kristus. Allah menghendaki keselamatan manusia karena kasih-Nya. Bersamaan dengan itu, ada gereja atau persekutuan orang Kristen sebagai sarana keselamatan. Jadi gereja juga menjadi ukuran. Karena itu, orang bisa selamat karena kasih Allah, tetapi karena ia tidak hidup dalam struktur Kekristenan, maka dia disebut "Kristen tanpa nama". Model ini sudah menunjukkan pandangan yang inklusif. ${ }^{17}$

Berbagai pendekatan tematis dalam menghadapi pluralitas agama telah dipergunakan, yaitu: pertama, teosentris yang mengutamakan pembahasan tentang Allah yang mengadakan perjanjian dengan nabi Nuh dan Abraham, yang berarti juga memasukan agama-agama lain yang satu keturunan dengan kekristenan, yaitu Yahudi dan Islam. Pendekatan teosentris ini menampakkan pandangan dan sikap yang inklusif terhadap pluralitas; bahwa agama-agama yang ada berada pada satu lingkungan dan kehidupan bersama yang semuanya berasal dari satu akar atau leluhur bersama, dan dari Tuhan yang sama. Pandangan ini memahami bahwa jalan menuju pusat ada banyak, tapi pusatnya hanya satu. Tokoh-tokoh seperti:

\footnotetext{
${ }^{17}$ Ibid.
}

Paul Tillich, John Hick dan W.C. Smith menganut pendekatan ini.

Kedua, kristosentris, yang mengutamakan pembahasan hubungan Kekristenan dengan pluralitas atau agamaagama lain dengan menonjolkan Yesus sebagai ukuran. Pendekatan ini mewujudkan pandangan dan sikap eksklusif, yaitu yang mengutamakan Kristus sebagai ukuran. Bahwa agamaagama lain dapat membawa keselamatan asalkan ia memenuhi syarat yang ada pada Yesus. Tokoh seperti Karl Rahner menonjol dalam teologi ini. Tokoh yang lebih eksklusif adalah Karl Barth.

Ketiga, dialogis, yang mendasarkan pemahaman bahwa setiap agama memiliki keyakinan dan teguh dan mutlak dan yang berbeda dengan agama lain. Dialog membawa para penganut agama mencapai sikap yang saling memahami dan menghormati. Inilah pandangan dan sikap pluralis. Tokoh-tokoh seperti Stanley Samartha dan Raimundo Panikkar menjadi pendukung telogi pluralis ini. ${ }^{18}$

\footnotetext{
${ }^{18}$ Untuk pembahasan lebih lanjut mengenai soal ini, lihat: Harold Coward, Pluralisme. Tantangan bagi Agama-Agama (terj.) (Yogyakarta: Kanisius, 1989); John Hick \& Paul F. Knitter (peny.), Mitos keunikan Agama Kristen (Terj.) (Jakarta: BPKGM, 2001); Paul F. Knitter, No Other Name? A Critical Survey of Christian Attitides toward the World of Religions (NY: Orbis Books, 1985); John Hick \& Paul F. Knitter (peny.), Mitos Keunikan Agama Kristen (Terj.) (Jakarta: BPK-GM, 2001); John Hick, A Christian Theology of Religions. The Rainbow of Faith (Kentucky: Westminster John
} 
Catatan-Catatan Konklusif: Pluralitas

\section{Agama dan PAK}

Pluralitas agama telah menjadi perhatian utama agama-agama, termasuk Kekristenan. Ini karena pluralitas agama telah menjadi realitas mutlak di dalam masyarakat, bahkan sejak jaman ketika proses pembentukan agama baru dimulai.

Di dalam Kekristenan, pluralitas dan pluralisme ini dihadapi sejak jaman para leluhur dan kemudian di masa para nabi. Di dalam perjumpaan itu, ada pandangan dan sikap yang eksklusif, inklusif dan juga pluralis. Demikian juga di masa pembentukan Kekristenan di jaman Yesus, murid-murid dan pengikut-pengikutnya. Ada eksklusivisme, inklusivisme dan pluralisme. Memang di dalam sejarah Kekristenan, di dalam perjumpaan dengan pihak-pihak lain, pandangan dan sikap yang eksklusif dan bahkan kadang ekstrim, telah menjadi unsur yang dominan. Pernyataan-pernyataan yang menunjukkan pandangan dan sikap pluralis yang mengakui dan menerima keberadaan pihak lain yang berbeda secara sungguh-sungguh dan tulus juga tampak. Bangsa-bangsa lain diterima sebagai saluran berkat Allah.

Knox Press, 1995). John Hick \& Brian Hebblethwaite (eds.), Christianity and Other Religions (Oxford: One World, 2001).
Pihak lain ini dipahami sebagai memiliki status dan peran yang sama.

Di dalam wacana Kekristenan kontemporer, topik pluralitas/pluralisme tetap menjadi perhatian utama. Pembahasan dan sikap terhadap topik ini tampak lebih sistematis dengan menghasilkan berbagai tiga model pandangan dan sikap. Pertama, eksklusifsuperior, yang mendorong ke arah pelaksanaan misi-pemenangan jiwa (jadi ada maksud konversi); kedua, inklusif, yang menilai agama atau pihak lain mengandung unsur-unsur kebenaran yang sama; dan ketiga, pluralis, yang menerima keberadaan pihak lain dan mengakui bahwa agama lain adalah tempat yang dipakai Allah untuk menyatakan dirinya. Jadi di dalam agama-agama, orang dapat mengenal, mendekati dan mendapat berkat dari Allah.

Akhirnya, pandangan dan sikap Kristen dalam menghadapi pluralitas di atas, terutama model inklusif dan pluralis, harus dapat mendorong umatnya untuk merumuskan kembali teologi berdasarkan pengalaman perjumpaan dalam pluralitas itu. Dengan kata lain, pandangan itu dapat menghasilkan rumusan-rumusan doktrin baru sebagai hasil dari atau yang sesuai dengan keadaan dan kebutuhan hidup beragama dalam masyarakat majemuk. Bahwa hendaknya, doktrin-doktrin yang dihasilkan sebagai pegangan umat 
beragama itu berasal dari pengalaman perjumpaan dengan umat agama lain, bukan doktrin yang diwarisi selama ini yang nyata-nyata berasal dari konteks sosial-budaya dan agama dengan jaman yang berbeda. Hal ini dapat didasarkan pada pemahaman bahwa Allah yang dipercayai di dalam agama-agama tidak hanya berkarya pada masa lampau ketika pembentukan konsep-konsep keagamaan awal, tetapi Ia juga hadir dan berkarya di dalam kehidupan manusia kini dan di sini. Untuk kebutuhan pembentukan rumusanrumusan teologi atau doktrin yang kontekstual, khususnya yang didasarkan pada pluralisme maka yang diperlukan pertama-tama adalah perjumpaan yang intensif dan positif, yang ditandai oleh dialog yang benar. Perjumpaam dan dialog seperti ini akan menghasilkan saling pengertian, saling menghormati dan kesadaran terhadap kebutuhan pada nilainilai moral-etis dan spiritual bersama yang membawa kepada hidup yang rukun, tentram dan damai, baik di tingkat lokal maupun global.

\section{Pengajaran Pendidikan Agama}

Kristen tentu sejalan dengan proses bertelogi. Pemahaman dan sikap teologis yang dipegang dan dilaksanakan oleh umat Kristen memiliki implikasi atau pengaruh terhadap usaha untuk mengajarkan ajaran dan nilai-nilai kristiani kepada naradidik. Dalam konteks masyarakat, khususnya di
Indonesia, dengan pluralitas agama dan umatnya, pengajaran PAK seharusnya dipengaruhi oleh konteks plural tersebut. Oleh karena itu, istilah PAK yang pluralis atau kontekstual menjadi keharusan, diterima dan diwujudnyatakan. Pendidikan apapun, jika itu dilakukan sesuai konteks, tentu akan efekif. Efektfitas sebuah proses pengajaran tentu mendukung tujuan pendidikan yang telah ditentukan melalui kurikulum yang dipergunakan. Kurikulum ini tentu sudah disesuaikan dengan tujuan pendidikan yang diataur dalam UndangUndang Pendidikan Nasional.

Untuk itu, pertama kurikulum dan khususnya materi atau bahan ajar perlu disesuaikan dengan konteks tersebut. Dalam hal ini, pluralitas agama diberi perhatian dan porsi yang cukup dan layak dan yang sangat penting adalah menjadikan pluralisme sebagai rohnya. Plularisme menjadi dasar, pertimbangan, dan corak utama di dalamnya. Kedua, para naradidik sebagai narasumber, siapapun mereka, yang terlibat dalam pengajaran PAK, perlu memiliki pengetahuan, wawasan dan keterampilan yang minimal memadai tentang kondisi plural agama masyarakat dan pluralisme menjadi prinsip dan karakter umum. Untuk itu, pendidikan pluralis terhadap mereka juga sangat dibutuhkan. Ketiga, latar belakang dan kondisi sosial, psikologis, religius para naradidik yang menerima pengajaran PAK 
dalam masyarakat plural ini perlu diberi

perhatian dan pertimbangan dalam pengajaran PAK plularis dan kontekstual. Keempat, dalam proses pengajaran PAK tersebut, diperlukan metode dan pendekatan yang tepat yang mempertimbangkan bahan ajar, kemampuan pengajar, kondisi siswa, fasilitas dan waktu yang tersedia.

Dengan pemahaman, penerimaan dan sikap yang tepat, yaitu pluralis dalam menghadapi kondisi masyarakat yang majemuk atau plural agama, tujuan kehadiran Kristen dalam masyarakat yang majemuk agama dapat sangat berarti.

Umat Kristen khususnya melalui lembaga-lembaga pendidikan, dapat menjalankan kehidupan beragama atau berimannya secara pribadi dengan efektif, sekaligus menjalankan peran positifnya di dalam masyarakat. Dengan pengajaran PAK yang pluralis, umat Kristen dapat menjadi agen-agen pendukung terciptanya kerukunan dan persatuan di dalam masyarakat.

\section{Daftar Bacaan:}

Alkitab. Jakarta: LAI, 1988.

Ariarajah, Wesley. Alkitab dan Orang-Orang Yang Berkepercayaan Lain (terj.) Jakarta: BPK-GM, 1987.

Coward, Harold. Pluralisme Agama Tantangan bagi Agama-Agama. Yogyakarta: Kanisius, 1989.

D'Costa, Gavin (Peny.). Mempertimbangkan Kembali Keunikan Agama Kristen (terj.). Jakarta: BPK-GM, 2002. 
Darmaputera, Eka (peny.). Konteks Berteologi di Indonesia. Buku penghormatan untuk HUT ke-70 Prof. Dr. P.D. Latuihamallo. Jakarta: BPK-GM, 1988.

Dupuis, Jacques. Toward A Christian Theology of Religious Pluralism. NY: Orbis Books, 1997.

Hardiyanto, S. dkk (peny.). Agama dalam Dialog. Pencerahan, Pendamaian dan Masa Depan. Jakarta: BPK-GM, 1999, Cet. 3, 2003.

Hastings, J., Encyclopedia of Religion and Ethics. (Vol. X). New York: Charles's Sons, 1951.

Hick, John \& Brian Hebblethwaite (eds.). Christianity and Other Religions. Oxford: One World, 2001.

Hick, John \& Paul F. Knitter (peny.). Mitos Keunikan Agama Kristen (terj.). Jakarta: BPK GM, 2001.

Hick, John. A Christian Theology of Religions. The Rainbow of Faith. Kentucky: Westminster John Knox Press, 1995.

Knitter, Paul F., No Other Name? A Critical Survey of Christian Attitides toward the World of Religions. NY: Orbis Books, 1985.

Knitter, Paul F. One Earth, Many Religions: Multifaith Dialogue \& Global Responsibility. New York: Orbis Books, 1995.

Kraemer, H. The Christian Message in A Non-Christian World. London: The Edinburgh House Press, 1938.

Leeuwen, Arend Th. van. Agama Kristen dalam Sejarah Dunia (terj.). Jakarta: BPKGM,1987.

Schumann, Olaf. Dialog Antar Umat Beragama. Dari Manakah Kita Bertolak? Jakarta: Departemen Litbang-PGI, 1982.

Scumann, Olaf. Dialog Antar Umat Beragama. Di Manakah Kita Berada Kini? Jakarta: lembaga Penelitian dan studi-PGI, 1980.

Siburian, Togardo. Kerangka teologi Religionum Misioner. Pendekatan Injili tentang Hubungan Kekristenan dengan Agama-agama Lain. Bandung: Sekolah Tinggi Teologia Bandung, 2004.

Sidjabat, W. Bonar. Religious Tolerance and the Christian Faith. Jakarta: BPK-GM, 1982.

Sumarthana, Th. dkk (Redaksi). Dialog: Kritik dan Identitas Agama. Yogyakarta: Penerbit Dian/Interfidei, 1993.

Tanya, Victor I. Pluralisme Agama dan Problema Sosial. Jakarta: Pustaka Cidesindo, 1998.

Tanya, Victor I. Tiada Hidup Tanpa Agama. Jakarta: BPK-GM, 1988.

Tim Balitbang PGI, Meretas Jalan teologi Agama-Agama di Indonesia. Theologia Religionum. Jakarta: BPK-GM, 1999, Cet. ke-3, 2003.

World Council of Churches, Iman Sesamaku dan Imanku: Sebuah Penuntun Studi untuk Memperkaya Penghayatan Teologi Kita Melalui Dialog Antar Agama (terj.). Jakarta: BPK-GM, 2005, Cet. ke-6.I 